\title{
Health crisis in Venezuela: Status of communicable diseases and implications for the European Union and European Economic Area, May 2019
}

Laura Espinosa ${ }^{1}$, Grazina Mirinaviciute ${ }^{1}$

1. European Centre for Disease Prevention and Control, Solna, Sweden

Correspondence: Laura Espinosa (laura.espinosa@ecdc.europa.eu)

Re-emerging diseases outbreaks are being reported in Venezuela since $2012 / 13$, following ongoing political and economic crisis. Healthcare system collapse has led to an increasing incidence and mortality from communicable diseases. Increasing movement of people between Venezuela and the European Union and European Economic Area (EU/EEA) creates a need for increased awareness of the infectious disease risks and requirements for appropriate investigation and treatment of individuals arriving from Venezuela; overall risk for EU/EEA citizens is low.

Since 2012/13, Venezuela has experienced a rapid deterioration of the public health situation due to an ongoing political and economic crisis [1]. This crisis has led to the collapse of the healthcare system, resulting in the re-emergence of previously controlled or eliminated communicable diseases and to the lack of proper provision of sanitation, goods, services and food security $[2,3]$. In March-April 2019, recurrent and prolonged electricity blackouts in large parts of the country affected the availability of running water, telecommunication within and outside the country, transportation, adequate food cooling (e.g. fridge/freezers), economic mobility and education [4]. The healthcare sector was affected by the closure of operating theatres and emergency rooms, lack of care for chronic patients requiring medical devices for their survival and lack of medicines and vaccines [4].

Here, we present the latest available information on communicable diseases in Venezuela and the possible implications that it may have in the European Union and European Economic Area (EU/EEA), hereafter referred to as Europe.

\section{Status of communicable diseases in Venezuela}

In December 2016, the latest national report on communicable diseases was published by the Venezuelan
Ministry of Health [5], in which an increase in infant and maternal mortality, a resurgence of diphtheria and an increase in the incidence of malaria, Zika, tuberculosis and hepatitis A was reported. The current situation of communicable diseases in Venezuela is available from reports from the World Health Organization (WHO), scientific research and studies/surveys on specific pathogens. Most of these sources acknowledge a noticeable gap between the reported and the estimated incidence or prevalence of some communicable diseases, thus the numbers in Table 1 demonstrate only confirmed cases and should be read with caution of possible underestimation (Table 1).

Vaccine preventable diseases

Diphtheria and measles have re-emerged due to vaccine shortages and lack of vaccination programmes, in July 2016 and in 2017, respectively. Between 2016 and 2018 , there have been 280 deaths from diphtheria. In 2018, there were over 5,000 confirmed measles cases, with $10 \%$ of the cases affecting indigenous populations in Amazonas and Delta Amacuro states [6].

\section{Mosquito-borne diseases}

Arboviruses, e.g. dengue, chikungunya and Zika virus, are an expanding threat in the country [7]. Due to interruptions of water supply and electricity, residents in Venezuela have to store water in receptacles that maintain favourable breeding conditions for Aedes mosquitoes. In addition, there is an increased possibility of severe dengue cases due to co-circulation of four dengue virus serotypes (DENV 1-4) [8]. Epidemics of chikungunya in 2014 and Zika virus in 2015-16 reported in Latin America also impacted the country with a high number of cases (Table 1).

Confirmed cases of malaria increased between 2016 and 2017, with 240,613 detected in 2016 and 414,000 malaria cases in 2017 - the highest annual total recorded since 1988 [9]. It has been estimated that 


\section{TABLE 1}

Latest available data on confirmed cases of communicable diseases and associated deaths in Venezuela, by disease and time period

\section{Disease}

Time period

Confirmed cases

Deaths

Source

Vaccine preventable diseases

\begin{tabular}{|c|c|c|c|c|}
\hline Diphtheria & W26 2016-Wo8 2019a & 1,612 & 280 & РAHO [16] \\
\hline \multirow{3}{*}{ Measles } & $W_{2} 62017-W_{52} 2017^{a}$ & 727 & 2 & РАHO [6] \\
\hline & 2018 & 5,667 & 74 & PAHO [6] \\
\hline & Wo1 2019-W13 2019 & 140 & NA & РAHO [6] \\
\hline
\end{tabular}

Mosquito-borne diseases

\begin{tabular}{|c|c|c|c|c|}
\hline \multirow{4}{*}{ Chikungunya } & 2014 & 2,303 & 0 & PAHO [17] \\
\hline & 2015 & 347 & 0 & РAHO [17] \\
\hline & 2016 & 355 & 0 & РAHO [17] \\
\hline & 2017 & 39 & 0 & PAHO [17] \\
\hline \multirow{3}{*}{ Dengue } & 2017 & 1,588 & 16 & PAHO [18] \\
\hline & 2018 & 2,440 & 24 & PAHO [18] \\
\hline & Wo1 2019-W17 2019 & 288 & 8 & PAHO [18] \\
\hline IVIdidid & 2017 & 414,000 & NA & WHO [9] \\
\hline \multirow{2}{*}{ Zika } & 2016 & 2,380 & 0 & PAHO [19] \\
\hline & 2017 & 2,413 & 0 & PAHO [19] \\
\hline \multicolumn{5}{|l|}{ Other vector-borne diseases } \\
\hline Chagas & Oct 2017-Apr 2018 & 40 & 8 & Grillet et al. 2019 [7] \\
\hline \multirow{3}{*}{ Oral Chagas disease } & May $2016^{a}$ & 5 & 0 & Grillet et al. 2019 [7] \\
\hline & Sep $2017^{a}$ & 6 & 3 & Grillet et al. 2019 [7] \\
\hline & Mar 2018 & 42 & 6 & Grillet et al. 2019 [7] \\
\hline & 2014 & Ca 1,750 & NA & Grillet et al. 2019 [7] \\
\hline & 2015 & Ca 2,000 & NA & Grillet et al. 2019 [7] \\
\hline & 2016 & Ca 2,000 & NA & Grillet et al. 2019 [7] \\
\hline \multicolumn{5}{|l|}{ HIV and tuberculosis } \\
\hline HIV & 2016 & $120,000 \mathrm{C}$ & 2,500 & UNAIDS [20] \\
\hline Tuberculosis & 2017 & $10,952 \mathrm{C}$ & 800 & WHO [21] \\
\hline
\end{tabular}

HIV: human immunodeficiency virus; NA: not available; PAHO: Pan American Health Organisation; WHO: World Health Organization.

${ }^{a}$ Time period corresponding to an outbreak.

${ }^{\mathrm{b}}$ Incomplete year.

'These are prevalent confirmed cases.

Only confirmed cases are reported in Table 1. There may be a possible underestimation of cases; therefore, numbers should be interpreted with caution. 


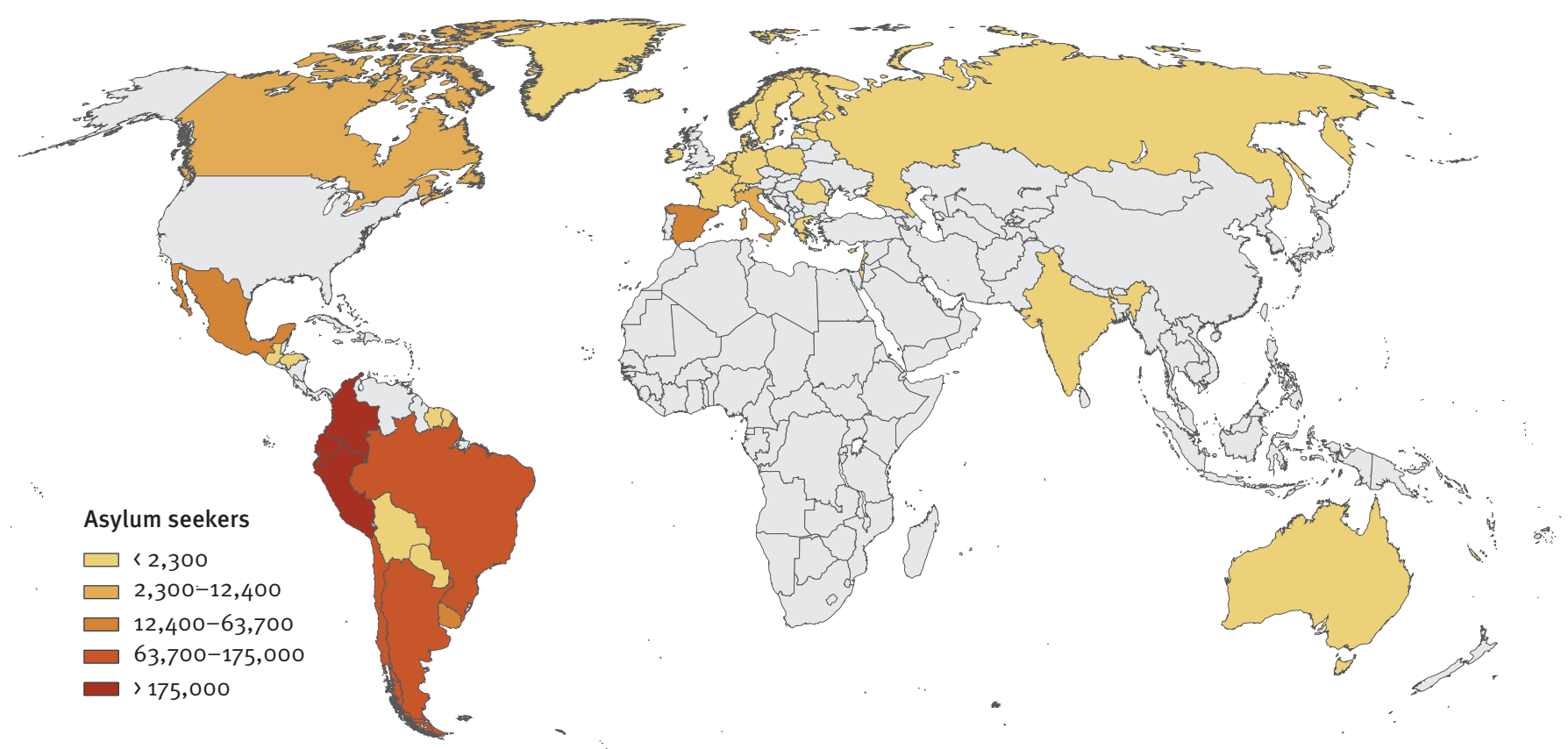

Source: United Nations High Commissioner for Refugees (UNHCR).

there were one million malaria cases in 2018 , including non-reported infections and relapses [10]. The surveillance programme against malaria has been gradually dismantled since 2012 [11].

\section{Other vector-borne diseases}

Additional vector-borne diseases have been reported in the country. The seroprevalence of Trypanosoma cruzi, which causes Chagas disease, has increased in recent decades following decentralisation of control measures in $1990 \mathrm{~s}$ and after the Chagas diseases programme was dismantled in 2012 [7]. Between October 2017 and April 2018 there were 40 confirmed cases of Chagas disease (Table 1). Leishmaniasis is widespread in the human and animal population, outbreaks of Mayaro virus have been reported in the past decade, Oropouche virus in the Amazonas state and the occurrence of epizootic strains of Venezuelan equine encephalitis [7].

\section{HIV and tuberculosis}

The latest available information on cases of HIV and tuberculosis from 2016 and 2017, respectively, can be seen in Table 1. The incidence rate of tuberculosis is the highest reported in the country for the past 40 years [12], with more than 10,000 confirmed cases in 2017 (Table 1).

\section{Asylum seekers and travellers returning from Venezuela}

An increased emigration of Venezuelan nationals has been reported since 2014 [7]. There were ca 1,750,000 Venezuelans reported to be seeking asylum between
January and June $2018,46 \%$ of whom applied for asylum in Peru, Ecuador or Colombia (Figure 1) [13].

In Europe, the number of Venezuelan asylum seekers increased from ca 320 in 2014 to more than 20,000 in 2018, with almost all applications being filed in five countries (Spain, Italy, France, Germany and Belgium) and ca $85 \%$ of these in Spain (Figure 1) [14]. According to the latest data from the European Asylum Support Office, there were ca 6,600 Venezuelan nationals applying for asylum in Europe in January-February 2019 [14].

In addition, there were ca 150,000 travellers returning from Venezuela to Europe in 2017, according to the International Air Transport Association (IATA) (Figure 2). Of these, $87 \%$ were returning to Spain, Portugal or Italy. The available data show the country of departure and destination of the air travel, but not the nationality of the travellers.

\section{Discussion and conclusions}

As a consequence of political and economic crisis, Venezuela faces a re-emergence of communicable diseases that were previously eliminated or controlled. Increasing numbers of people are affected by an increased incidence of infectious diseases (and outbreaks) and mortality, which may be underestimated in the absence of proper surveillance and lack of treatment; thus, the magnitude of the outbreaks may be larger than presented. In addition, the mass departure of trained medical personnel reported in recent years is having an impact on the proper care of patients [7]. People with chronic health conditions, pregnant and 
Geographic distribution of travellers returning from Venezuela to the EU/EEA, January-December 2017 $(n=150,000)$

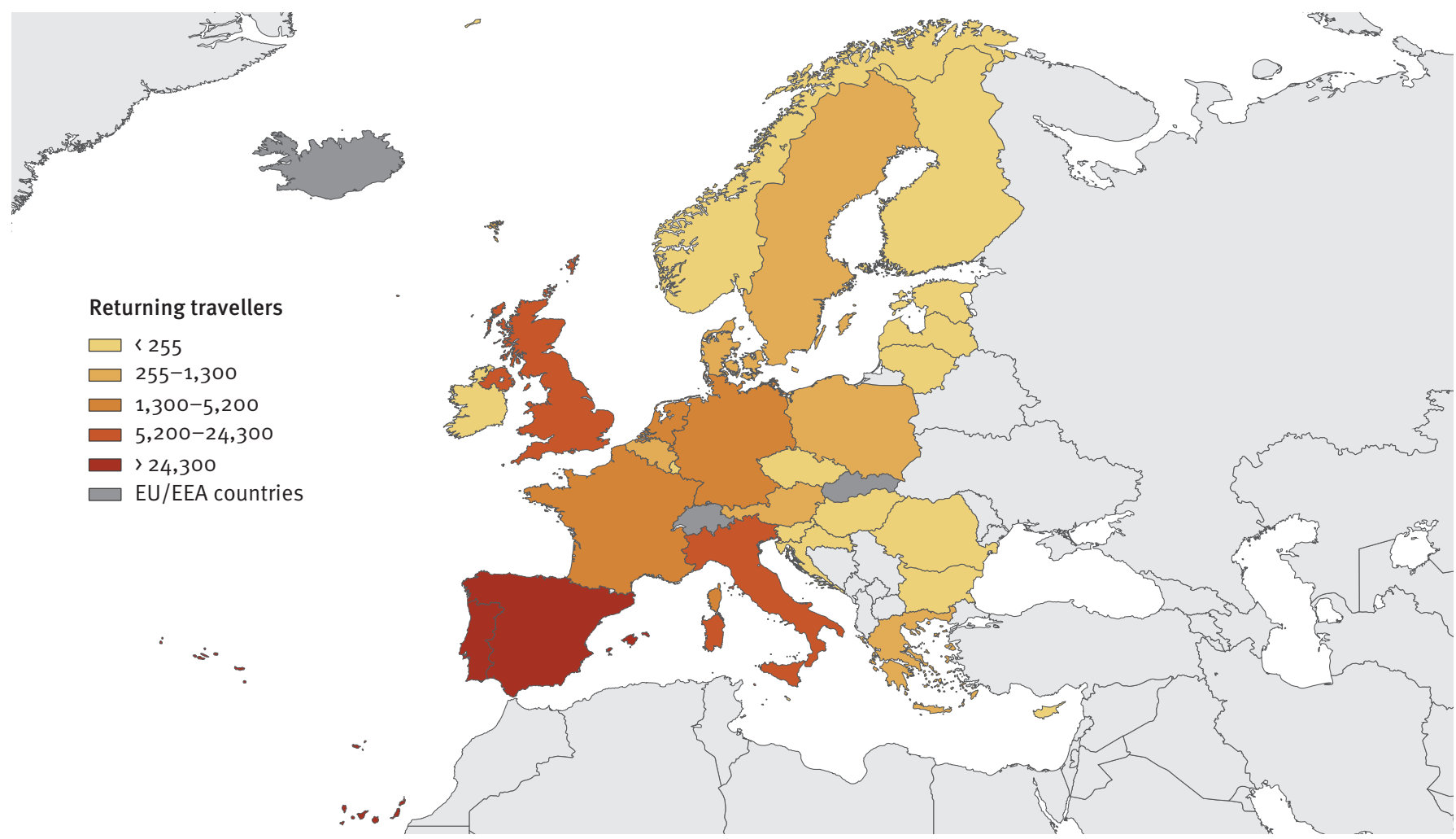

EU/EEA: European Union and European Economic Area.

Source: International Air Transport Association (IATA).

nursing women, children under 5 years, indigenous population, people without a fixed residence and those living with disabilities are among the most vulnerable [12].

The migration of people from Venezuela to neighbouring countries and to Europe requires increased awareness that Venezuelans (in particular the aforementioned risk groups) are facing heightened infectious disease risks and that there is a need for appropriate investigation and treatment by healthcare providers in the receiving countries.

The situation in Venezuela and travel to and from the country increases the possibility for European citizens of being exposed to circulating infectious diseases. Previous outbreaks in neighbouring and European countries have been shown to have originated from Venezuela, such as a Chagas disease outbreak in Colombia in 2017-18 [7] and dengue outbreak in Madeira in 2012 [15].

The deterioration in public health systems e.g. vaccination programmes in Venezuela also means that migrants to Europe may be at risk from diseases present in Europe, such as measles. Therefore, Venezuelan migrants residing in Europe should be recommended to seek advice from healthcare providers on vaccination requirements in the country of residence. They should also be advised to seek immediate medical advice and mention that they have recently arrived from Venezuela in case of symptoms suggestive of gastrointestinal, respiratory, cutaneous or any other type of infection. The travellers visiting Venezuela should be appropriately vaccinated, follow good hygiene practices, practice safe sex and use preventive measures against mosquito bites to prevent vaccine-preventable diseases such as measles, food- and water-borne diseases, sexually transmitted infections such as HIV and mosquito-borne diseases such as dengue or malaria, among others. Currently, the overall risk for severe diseases is considered low for European residents and returning travellers from Venezuela if public health advice is followed.

\section{Aknowledgements}

The views and opinions expressed herein are the authors' own and do not necessarily state or reflect those of ECDC.

Conflict of interest

None declared.

\section{Authors' contributions}

LE drafted the manuscript with significant input from GM. LE analysed the data. All authors critically revised and approved the manuscript. 


\section{References}

1. Page KR, Doocy S, Reyna Ganteaume F, Castro JS, Spiegel $P$, Beyrer C. Venezuela's public health crisis: a regional emergency. Lancet. 2019;393(10177):1254-60. https://doi. org/10.1016/S0140-6736(19)30344-7 PMID: 30871722

2. Tuite AR, Thomas-Bachli A, Acosta H, Bhatia D, Huber C, Petrasek K, et al. Infectious disease implications of large-scale migration of Venezuelan nationals. J Travel Med. 2018;25(1). https://doi.org/10.1093/jtm/tayo77 PMID: 30192972

3. Doocy S, Ververs MT, Spiegel P, Beyrer C. The food security and nutrition crisis in Venezuela. Soc Sci Med. 2019;226:63 8. https://doi.org/10.1016/j.socscimed.2019.02.007 PMID: 30849671

4. Publico. Además de la luz, ¿qué pierde Venezuela con los apagones? [Besides light, what does Venezuela lose with the blackouts?]. Madrid: Público; 2019 [Accessed 10 May 2019]. Spanish. Available from: https://www.publico.es/ internacional/venezuela-ademas-luz-pierde-venezuelaapagones.html

5. Gobierno Bolivariano de Venezuela. Boletín Epidemiológico - Semana Epidemiológica $N^{\circ} 52$ [Epidemiological Bulletin - Epidemiological Week $N^{\circ}$ 52]. Caracas: GBV; 2016. Spanish. Available from: https://www.ovsalud.org/ descargas/publicaciones/documentos-oficiales/BoletinEpidemiologico-2016.pdf

6. Pan American Health Organization (PAHO). Measles: Epidemiological alerts and updates by disease. Washington: PAHO; [Accessed 10 May 2019]. Available from: https://www. paho.org/hq/index.php?option=com_topics\&view=rdmore\&cid $=2204$ \&ltemid=40899\&lang=en

7. Grillet ME, Hernández-Villena JV, Llewellyn MS, PanizMondolfi AE, Tami A, Vincenti-Gonzalez MF, et al. Venezuela's humanitarian crisis, resurgence of vector-borne diseases, and implications for spillover in the region. Lancet Infect Dis. 2019;19(5):e149-61. https://doi.org/10.1016/S14733099(18)30757-6 PMID: 30799251

8. Shrivastava S, Tiraki D, Diwan A, Lalwani SK, Modak M, Mishra AC, et al. Co-circulation of all the four dengue virus serotypes and detection of a novel clade of DENV-4 (genotype I) virus in Pune, India during 2016 season. PLoS One. 2018;13(2):e0192672. https://doi.org/10.1371/journal. pone.0192672 PMID: 29470509

9. World Health Organization (WHO). World malaria report 2018. Geneva: WHO; 2018. Available from: https://www.who.int/ malaria/publications/world-malaria-report-2018/en/

10. Amaya V. Éstas son las seis plagas que azotan Venezuela [These are the six plagues that hit Venezuela]. Caracas:La Razón; 2019. Spanish. Available from: https://www.larazon.es/ internacional/la-malaria-se-extiende-por-venezuela-y-registraya-un-millon-de-casos-NB23000937.

11. FAMME. Malaria: El repunte de una de las enfermedades más antiguas del mundo. [Malaria: re-emergence of one of the oldest disease in the world]. Madrid: Medicus Mundi; 2019 Spanish. Available from: https://www.medicusmundi. es/es/actualidad/noticias/1075/Malaria\%2orepunte\%20 enfermedad\%20antigua\%2omundo.

12. John Hopkins Bloomber School of Public Health and John Hopkins Center for Humanitarian Health. Human Rights Watch: Venezuela's humanitarian emergency. Large-scale UN response needed to address health and food crises. Baltimore: Johns Hopkins Bloomberg School of Public health; 2019. Available from: https://www.hrw.org/sites/default/files/report_pdf/ venezuelao419_web.pdf

13. United Nations High Commissioner for Refugees (UNHCR). Population statistics database. Geneva: UNHCR; 2019 [cited 2019 May 10]. Available from: http://popstats.unhcr.org/en/ overview

14. European Asylum Support Office(EASO). Latest asylum trends. Valetta: EASO; [Accessed 10 May 2019]. Available from: https://www.easo.europa.eu/latest-asylum-trends

15. Franco L, Pagan I, Serre Del Cor N, Schunk M, Neumayr A, Molero F, et al. Molecular epidemiology suggests Venezuela as the origin of the dengue outbreak in Madeira, Portugal in 20122013. Clin Microbiol Infect. 2015 Jul;21(7):713 e5-8.

16. Pan American Health Organization (PAHO). Epidemiological Update Diphtheria. Washington: PAHO; [Accessed 10 May 2019]. Available from: https://www.paho.org/hq/index. php?option =com docman\&view=download\&slug $=18-$ march2019-diphtheria-epidemiological-update\&Itemid=270\&lang=en

17. Pan American Health Organization (PAHO). Chikungunya: Data, maps and statistics. Washington: PAHO; [Accessed 10 May 2019]. Available from: https://www.paho.org/hq/index. php?option $=$ com_topics \&view $=$ rdmore $\&$ cid $=5927 \&$ item $=$ chiku ngunya\&type $=$ statistics \& Itemid $=40931 \&$ lang $=$ en
18. Pan American Health Organization (PAHO). Reported cases of dengue fever in the Americas. Washington: PAHO; [Accessed 10 May 2019]. Available from: http://www.paho.org/data/index. $\mathrm{php} / \mathrm{en} / \mathrm{mnu}$-topics/indicadores-dengue-en/dengue-nacionalen/252-dengue-pais-ano-en.html

19. Pan American Health Organization (PAHO). Zika cumulative cases. Washington: PAHO; [Accessed10 May 2019]. Available from: https://www.paho.org/hq/index. php?option $=$ com content\&view $=$ article\&id $=12390: z i$ ka-cumulative-cases \&Itemid $=42090 \&$ lang $=$ en

20. Joint United Nations Programme on HIV/AIDS (UNAIDS). Country Venezuela. Geneva: UNAIDS; 2017 [cited 2019 May 10]. Available from: http://www.unaids.org/en/regionscountries/ countries/venezuela

21. World Health Organization WHO). Global tuberculosis report 2018. Geneva: WHO; 2018. Available from: https://www.who. int/tb/publications/global_report/en/

\section{License, supplementary material and copyright}

This is an open-access article distributed under the terms of the Creative Commons Attribution (CC BY 4.0) Licence. You may share and adapt the material, but must give appropriate credit to the source, provide a link to the licence and indicate if changes were made.

Any supplementary material referenced in the article can be found in the online version.

This article is copyright of the authors or their affiliated institutions, 2019. 